


\title{
Present Innovation Policy: Russian Regions Data
}

\author{
DOI: https://doi.org/10.46398/cuestpol.3969.08
}

\author{
Iuliia S. Pinkovetskaia * \\ Natalya R. Aleksandrova ** \\ Tatyana V. Treskova *** \\ Daniela S. Veas Iniesta ****
}

\section{Abstract}

Innovation policies are currently one of the main axes for improving the efficiency of national economies in developed and developing countries. The innovation policy includes a comprehensive system of activities. In Russia, increasing the specific weight of commercial entities engaged in innovative activities is among the most important objectives for the short term. The aim of our study was to evaluate the use of innovation based on taking into account the specific weight of organizations that perform innovations in the total number of organizations operating in the regions of Russia. Our study was based on official statistical information on the 82 regions of Russia for 2017-2019. Economic-mathematical models have been developed that describe the specific weight of the organizations that implement innovation. There are no significant changes in the indicators for the years indicated. It has been shown that, to date, almost one in five organizations in the Russian Federation has used innovation in their activities. In addition, they have identified the regions with maximum and minimum values of the specific weightings of innovative organizations for 2019.

Keywords: innovation policy; innovations; innovative organizations; regions of Russia; functions of normal distribution.

PhD, Associate Professor, Department of Economic analysis and state management, Ulyanovsk State University, Ulyanovsk, Russia. ORCID ID: https://orcid.org/oooo-0002-8224-9031. Email: pinkovetskaia@gmail.com

** PhD, Associate Professor, Department of Economics, organization and management at the enterprise, Ulyanovsk State Agrarian University named after P.A. Stolypin, Ulyanovsk, Russia, ORCID ID: http:// orcid.org/oooo-0002-8711-8313. Email: aleksandrova_nr@mail.ru

** PhD, Associate Professor, Department of Finance and credit, Ulyanovsk State Agrarian University named after P.A. Stolypin, Ulyanovsk, Russia, ORCID ID: http://orcid.org/oooo-0001-7478-0095. Email: treskova77@mail.ru

**** Researcher, Institute of Engineering economics and humanities, Moscow Aviation Institute (National Research University), Moscow, Russia, ORCID ID: https://orcid.org/oooo-0002-8473-0670. Email: danonik92@mail.ru 


\section{Política de innovación moderna: datos de las regiones de Rusia}

\section{Resumen}

Las políticas de innovación son actualmente uno de los principales ejes para mejorar la eficiencia de las economías nacionales en los países desarrollados y en desarrollo. La política de innovación incluye un sistema integral de actividades. En Rusia, el aumento del peso específico de las entidades comerciales que realizan actividades innovadoras se incluye entre los objetivos más importantes para el corto plazo. El objetivo de nuestro estudio fue evaluar el uso de la innovación sobre la base de tener en cuenta el peso específico de las organizaciones que realizan innovaciones en el número total de organizaciones que funcionan en las regiones de Rusia. Nuestro estudio se basó en información Estadística oficial sobre las 82 regiones de Rusia para 2017-2019. Se han desarrollado modelos económicomatemáticos que describen el peso específico de las organizaciones que implementan la innovación. No hay cambios significativos en los indicadores de los años indicados. Se ha demostrado que, hasta la fecha, casi una de cada cinco organizaciones de la federación rusa ha utilizado la innovación en sus actividades. Adicionalmente, se han identificado las regiones con valores máximos y mínimos de las ponderaciones específicas de las organizaciones innovadoras para 2019.

Palabras clave: política innovadora; innovación en Rusia; organizaciones innovadoras; regiones de Rusia; funciones de la distribución normal.

\section{Introduction}

Over the past three decades, there has been a strong view that politics can influence innovation (Schot and Steinmueller, 2018). Accordingly, the term "innovation policy" has become widely used to describe the actions of various governments that have a significant impact on increasing the role of innovation in economic performance and overcoming existing problems (Edquist, 2011). It should be noted that previously, innovation policy was described in research as a scientific, research, industrial or technological policy. Accordingly, innovation policy is a broader concept and includes a comprehensive holistic system of measures to influence the state on the economy in order to increase its efficiency (Choi, 2017). Significantly, in addition to economic goals, it seeks to link scientific and technical activities with political goals aimed at improving the well-being of people, the sustainability of firms, and solving social problems (Geels, 2004). 
In most developed and developing countries, governments set specific goals to enhance and support innovation (Howlett, 2011; OECD, 2010). At the same time, the following goals are achieved:

- analysis of the impact of innovations on socio-economic development.

- identifying barriers that prevent the use of innovations, overcoming which will increase the chances modernization of success in production processes.

- measuring the effectiveness of different policy options in the field of innovation.

- comparative analysis of innovation activity in specific countries with indicators for other countries.

It is important for investment policy to take into account the characteristics characteristic of various types of economic activities (Mazzucato and Penna, 2016). Such an approach should take into account the exchange of technology between different industries and increase macroeconomic stability by stimulating firm activity (Hausman and Rodrik, 2003).

Policies that address the challenges of increasing innovation should involve a wide range of government and public organizations (Foray, 2018).

In recent years, Russia has formed high expectations for the growth of innovation in the economy. Based on the introduction of innovations, it is planned to move to more technological and efficient forms and methods of activity of enterprises and organizations. In Russia, innovation policy is currently determined by the provisions set out in Presidential Decree No. 204 (2018). This document provides for an increase in the number of organizations that have implemented innovations to fifty percent of their total number. The problem of increasing innovation activity is relevant in modern conditions. It seems logical to develop innovations in all regions of Russia. Next, our paper discusses the theoretical aspects of innovation policy, the review of the scientific research carried out on this issue, the methodology and design of our work and its results.

\section{Theoretical frameworks}

Innovation is now the main focus for addressing the pressing social and economic challenges posed by policy makers in most countries. At the same time, innovation policy requires governments to clearly formulate the tasks that can be solved in the near future with the use of innovations. A policy that ensures the trust of the majority of firms, which is valid for a long time and does not experience frequent changes, seems to be appropriate (Fagerberg 
et al., 2016). An effective mechanism for transforming the economy through innovation is to increase subsidies for research and development. Such subsidies are particularly important for small businesses (Castellacci and Mee Lie, 2015). In addition, tax burden reduction can be used (Larédo et al., 2016). The right choice of policy mechanisms should be based on a deep understanding of the existing barriers to the use of innovation. The most difficult stage of using innovation is the survival of firms between two stages: the formation of innovative ideas and their implementation. Therefore, innovation policy should be based on supporting firms that experiment and innovate at an early stage (Lauber and Jacobsson, 2015).

It should be noted that innovation policy should include not only hightech activities (for example, manufacturing), but also all other sectors of national economies (Martin, 2013), including trade, services (Benaim and Tether, 2016), as well as social activities (Van der Have and Rubalcaba, 2016). Innovation policy cannot rely solely on government support, but must rely on the coordination of all economic actors, including private enterprises (Kuhlmann and Rip, 2014).

The development of an effective innovation policy is a complex problem associated with the increased participation of public administration bodies and all interested sides in the formation of appropriate measures. Most of the innovations that had a great impact on the efficiency of the economic sector were based on such approaches (Mazzucato and Semieniuk, 2017; Edler and Fagerberg, 2017).

To date, three types of political instruments have emerged:

- support for basic research, the commercialization of which is difficult in the near future. Therefore, the government should allocate the necessary funds to universities and other research centers to ensure innovation based on such research.

- assisting corporations and firms that develop new technological and design work (Mohnen et al., 2017).

- increase of level of legal protection of property rights in developed and used innovation.

The implementation of public policy instruments can be carried out in regulatory, economic, and financial ways (Borrás and Edquist, 2013; Karakashian, 2015).

When forming an innovation policy, it is necessary to take into account five main elements (Fagerberg, 2017):

- knowledge that is formed by state research organizations and universities, as well as supplemented by their own developments of various firms. 
- skills, both highly specialized and general, that are formed in educational processes, including professional training of people.

- availability of demand for innovative solutions by creating appropriate markets, as well as using public procurement.

- state financing of innovative initiatives of small enterprises and individual entrepreneurs, as well as reducing the tax burden on these categories of actors.

- improving the institutional support of economic processes based on the promotion of innovation in legislative and regulatory acts, based on the needs of the business community.

\section{Literature review}

Scientific research examines innovations related to changes in existing knowledge, technological processes, the use of new technology and other opportunities and resources in various types of economic activities (Fagerberg et al., 2010), including low-tech and high-tech (Tunzelmann and Acha, 2004), in the service sector (Rubalcaba et al., 2012).

The analysis of innovation policy is based on the assessment of national innovation systems that ensure the interaction of innovation actors (Bergek et al., 2008; Hekkert and Negro, 2009; Weber and Truffer, 2017). In recent years, the study of the features of national innovation systems has become particularly relevant and has included an analysis of the factors that affect the effectiveness of such systems (Liu and White, 2001; Smits and Kuhlmann, 2004). Since 1991, the countries of the European Union have been collecting information describing not only the innovation activities of firms, but also the factors influencing them (Smith, 2004). It should be noted that the processes of mutual influence of elements of national innovation systems in most cases are stable, despite the changes occurring in the regions (Pierson, 2000). Therefore, regional innovations can vary greatly among themselves.

A number of scientific publications are devoted to the problem of innovation activity in Russia. We discuss the most interesting of them, which were published in 2019-2020. A brief description of these publications is given in table 1. 
CUESTIONES POLÍTICAS

Vol. 39 No 69 (Julio - Diciembre 2021): 146-163

\begin{tabular}{|c|c|c|c|c|}
\hline Authors & Studied questions & $\begin{array}{l}\text { Period, } \\
\text { years }\end{array}$ & $\begin{array}{l}\text { Objects of } \\
\text { innovation }\end{array}$ & $\begin{array}{c}\text { Type of } \\
\text { indicators }\end{array}$ \\
\hline 1 & 2 & 3 & 4 & 5 \\
\hline $\begin{array}{l}\text { Petrikov } \\
(2019)\end{array}$ & $\begin{array}{l}\text { Analysis of the } \\
\text { directions of innovation } \\
\text { activity, priority for } \\
\text { individual regions }\end{array}$ & $\begin{array}{l}2016- \\
2017\end{array}$ & $\begin{array}{c}\text { Regions of } \\
\text { the Central } \\
\text { Federal } \\
\text { District } \\
\end{array}$ & indices \\
\hline $\begin{array}{l}\text { Podsolonko } \\
\text { et al. (2019) }\end{array}$ & $\begin{array}{c}\text { Analysis of the } \\
\text { transfer of innovative } \\
\text { technologies by type of } \\
\text { economic activity }\end{array}$ & $\begin{array}{l}2010- \\
2016\end{array}$ & Russia & indices \\
\hline $\begin{array}{l}\text { Arkhipova et } \\
\text { al. (2019) }\end{array}$ & $\begin{array}{l}\text { Assessment of the } \\
\text { volume of innovative } \\
\text { goods produced and } \\
\text { services rendered, and } \\
\text { work performed by } \\
\text { small businesses } \\
\end{array}$ & 2016 & $\begin{array}{l}\text { Russian } \\
\text { regions }\end{array}$ & absolut \\
\hline $\begin{array}{l}\text { Zhuravlev } \\
\text { (2020) }\end{array}$ & $\begin{array}{l}\text { Assessment of the } \\
\text { degree of readiness of } \\
\text { the regional economic } \\
\text { complex for innovation } \\
\text { based on regression } \\
\text { analysis }\end{array}$ & $\begin{array}{l}2007^{-} \\
2017\end{array}$ & $\begin{array}{l}\text { Regions of } \\
\text { the Central } \\
\text { and North- } \\
\text { Western } \\
\text { Federal } \\
\text { Districts }\end{array}$ & absolute \\
\hline $\begin{array}{l}\text { Belemaeva } \\
\text { and } \\
\text { Kalimullin } \\
(2020) \\
\end{array}$ & $\begin{array}{c}\text { Increase in the market } \\
\text { capitalization of a } \\
\text { company that regularly } \\
\text { innovated }\end{array}$ & $\begin{array}{l}2001^{-} \\
2012\end{array}$ & $\begin{array}{c}\text { One } \\
\text { company }\end{array}$ & absolute \\
\hline $\begin{array}{l}\text { Deputatova } \\
\text { and } \\
\text { Perelman } \\
(2020) \\
\end{array}$ & $\begin{array}{c}\text { Analysis of innovative } \\
\text { technologies and } \\
\text { methods for attracting } \\
\text { buyers }\end{array}$ & $\begin{array}{l}2015^{-} \\
2018\end{array}$ & $\begin{array}{l}\text { Trade sector } \\
\text { in Russia }\end{array}$ & absolute \\
\hline $\begin{array}{l}\text { Yezhov } \\
(2020)\end{array}$ & $\begin{array}{c}\text { Dynamics of changes } \\
\text { in innovative activity of } \\
\text { enterprises. Business } \\
\text { participation in } \\
\text { scientific developments. } \\
\text { Barriers to innovation }\end{array}$ & $\begin{array}{l}2014^{-} \\
2018\end{array}$ & Russia & $\begin{array}{l}\text { absolute, } \\
\text { specific }\end{array}$ \\
\hline $\begin{array}{l}\text { Kudryavtseva } \\
\text { (2020) }\end{array}$ & $\begin{array}{l}\text { Institutional aspects of } \\
\text { state } \\
\text { support for innovations } \\
\text { in production } \\
\text { technologies }\end{array}$ & $\begin{array}{l}2012- \\
2015\end{array}$ & Countries & indices \\
\hline $\begin{array}{l}\text { Lipovka and } \\
\text { Arnautova } \\
(2020)\end{array}$ & $\begin{array}{l}\text { Innovative development } \\
\text { based on information } \\
\text { technologies }\end{array}$ & $\begin{array}{l}2015- \\
2018 \\
\end{array}$ & Gypermarket & absolute \\
\hline
\end{tabular}


Iuliia S. Pinkovetskaia, Natalya R. Aleksandrova, Tatyana V. Treskova y Daniela S. Veas Iniesta

\begin{tabular}{|c|c|c|c|c|}
\hline $\begin{array}{c}\text { Smirnova } \\
\text { (2020) }\end{array}$ & $\begin{array}{c}\text { Dynamics of changes in } \\
\text { the share of innovative } \\
\text { enterprises. Factors that } \\
\text { reduce the effectiveness } \\
\text { of innovation } \\
\text { implementation }\end{array}$ & $\begin{array}{c}\text { 2000- } \\
2014\end{array}$ & Russia & specific \\
\hline
\end{tabular}

Table 1. Scientific publications on innovation in Russia

Note: Achieved by the authors

Based on the information given in Table 1, it can be stated that the problem of studying regional innovation activity is relevant in Russia. At the same time, in theoretical and applied research to date, unjustifiably little attention has been paid to the comparative analysis of the activities of organizations (enterprises) that carried out technological innovations in the regions of Russia. In the same works where such an analysis was available, the absolute values of innovation activity were compared, as a rule, which is not always logical, since regions differ significantly in the number of economic entities, population, size and location.

\section{Methodology and design}

The purpose of our study was to assess the levels of innovation use based on the share of innovative organizations in the total number of organizations operating in the regions of Russia.

The main aspects of evaluation innovation activities of organizations are presented in detail in the document (OECD, 2018). At the same time, innovations are understood as the release of new or improved products (goods and services) that are significantly different from previously produced products, as well as the introduction of new or more advanced production processes in organizations that are significantly different from those that were previously used. Accordingly, innovations can be of two types. The first type of innovation involves better products and services, and the second type is associated with changes in production processes. Both of these types of innovations are united by such a concept as technological innovation. It should be noted that innovations aimed at creating new or improving existing production processes, in turn, are divided into the following subspecies:

- changes in production technologies and the creation of new products (goods and services) in various industries. 
- changes in logistics, transport, and distribution operations related to the supply of organizations and the sale of finished products.

- improving the technology and organization of information processes.

- use of more effective methods of conducting and managing production activities, including accounting and control issues.

- development of interaction of organizations with the external environment.

- improving the effectiveness of personnel policy.

- improvement of methods and forms of marketing and pricing.

An analysis of the previous studies, including those shown in Table 1, allowed us to conclude that it is advisable to use the share of innovative organizations in the total number of all organizations in each of the regions of Russia as an indicator of the level of innovation activity in the regions.

The research process included three stages. At the first stage, the initial empirical data describing the share of innovative organizations in the total number of organizations operating in the regions of Russia were formed. At the second stage, the distribution of specific values innovation organizations across the country's regions was evaluated. At the third stage, a comparative analysis was carried out, during which the regions of the country were established, in which the minimum and maximum values of specific innovations were noted.

As initial information, the study used official statistics for 2017-2019 on the share of innovative organizations in the total number of organizations in 82 regions of Russia (Federal State Statistics Service, 2021).

In the economic and mathematical modeling used to estimate the distribution of specific innovation values across the country's regions, the normal distribution function was used. The papers (Pinkovetskaia and Slepova, 2018; Pinkovetskaia et al., 2021) presents a methodological approach to the development and use of such a function to determine the average value of the indicator for the considered regions, as well as the range of its variation.

The study included testing the following three hypotheses:

- hypothesis 1 - the average values of indicators characterizing the share of Russian organizations that implemented technological innovations did not change significantly over the period from 2017 to 2019.

- hypothesis 2 - the values of the share of innovative organizations in the total number of organizations have a significant differentiation across different regions. 
- hypothesis 3 - the territorial location of regions does not significantly affect the values of the share of innovative organizations in the total number of organizations.

\section{Results of calculation experiment}

During the computational experiment, economic and mathematical modeling was carried out on the basis of empirical data. The models that describe the distribution of the three indicators for different years across 82 regions of Russia are shown below:

- the share of innovative organizations in the total number of organizations by region in $2017, \%$

$$
y_{1}\left(x_{1}\right)=\frac{585.71}{7.46 \times \sqrt{2 \pi}} \cdot e^{-\frac{\left(x_{1}-18.87\right)^{2}}{2 \times 7.46 \times 7.46}}
$$

- the share of innovative organizations in the total number of organizations by region in $2018, \%$

$$
y_{2}\left(x_{2}\right)=\frac{644.29}{7.67 \times \sqrt{2 \pi}} \cdot e^{\frac{-\left(x_{2}-17.68\right)^{2}}{2 \times 7.67 \times 7.67}} \text {; }
$$

- the share of innovative organizations in the total number of organizations by region in $2019, \%$

$$
y_{3}\left(x_{3}\right)=\frac{644.29}{7.94 \times \sqrt{2 \pi}} \cdot e^{-\frac{\left(x_{3}-18.50\right)^{2}}{2 \times 7.94 \times 7.94}} \text {. }
$$

The high quality of functions (1)-(3) was confirmed in the testing process according to the Shapiro-Wilk, Pearson and Kolmogorov-Smirnov criteria.

\section{Discussion}

At the next stage of the study, patterns were identified that characterize the distribution of the considered indicators. Column 2 (Table 2) shows the data describing the average values of the indicators. The ranges in which the values of the indicators for most regions are located are shown in the third column of the table. 


\begin{tabular}{|c|c|c|}
\hline Year & Medium values & Values for most regions \\
\hline 1 & 2 & 3 \\
\hline 2017 & 18.87 & $11.41-26.33$ \\
\hline 2018 & 17.68 & $10.01-25.35$ \\
\hline 2019 & 18.50 & $10.56-26.44$ \\
\hline
\end{tabular}

Table 2. Values of indicators that characterize the share of innovative organizations in the total number of organizations, \%

Note: Achieved by the authors on the base of functions (1)-(3)

The data shown in Table 2 shows that the share of innovative organizations in the total number of organizations operating in the regions was in the range from $17.6 \%$ to $18.9 \%$ in $2017-2019$. That is, on average, in the regions under consideration, every fifth organization participated in innovation activities. It should be noted that during this period, no significant changes were observed, both in the average values and in the values typical for most regions. That is, the first hypothesis was confirmed:

To test hypothesis 2, the data presented in column 3 of Table 2 were analyzed. The analysis showed a significant differentiation in the considered regions of the values of indicators for all years. Therefore, the second hypothesis was confirmed.

At the next stage, the regions where the maximum and minimum values of each of the indicators were noted in 2019 were identified. At the same time, the maximum and minimum values are those that correspondingly exceed the upper limits of the ranges shown in the third column of Table 1 and are smaller than the lower limits of the ranges. The results of this analysis are shown in Table 3. Along with the lists of regions, this table also shows the division of the identified regions by their geographical location and the specific weights of innovative organizations in the regions, which are given in parentheses. 
Iuliia S. Pinkovetskaia, Natalya R. Aleksandrova, Tatyana V. Treskova y Daniela S. Veas Iniesta Present Innovation Policy: Russian Regions Data

\begin{tabular}{|c|c|c|}
\hline Indicator & Maximum values & Minimum values \\
\hline 1 & 2 & 3 \\
\hline $\begin{array}{l}\text { share of } \\
\text { innovative } \\
\text { organizations } \\
\text { in the total } \\
\text { number of } \\
\text { organizations } \\
\text { by region in } \\
2019\end{array}$ & $\begin{array}{l}\text { Cities Moscow (45.1\%), } \\
\text { St. Petersburg (33.7\%), } \\
\text { Sevastopol (33.3\%), the } \\
\text { Republics of Mordovia } \\
\text { (34.8\%), Chuvash (33.6\%), } \\
\text { Tatarstan (26.5\%), Rostov } \\
\text { (32.0\%), Ryazan (31.5\%), } \\
\text { Tomsk (27.8\%), Moscow } \\
\text { (27.5\%), Belgorod (26.7\%), } \\
\text { Nizhny Novgorod (26.6\%) } \\
\text { regions. They are located in } \\
\text { the Central (four regions), } \\
\text { North-Western (one region), } \\
\text { Volga (four regions), } \\
\text { Southern (two regions), and } \\
\text { Siberian (one region) federal } \\
\text { districts. }\end{array}$ & $\begin{array}{c}\text { The Republics of Karachay- } \\
\text { Cherkessia (10.1\%), Altai } \\
\text { (9.7\%), Tyva (8.8\%), Kalmykia } \\
\text { (6.1\%), North Ossetia - Alania } \\
\text { (4.8\%), Dagestan (4\%), } \\
\text { Chechnya (1.5\%), Chukotka } \\
\text { Autonomous Okrug (9.4\%), } \\
\text { Kemerovo (10.3\%), Sakhalin } \\
\text { (10.0\%), Orenburg (9.3\%), } \\
\text { Kostroma (8.6\%), Krasnodar } \\
\text { (10.3\%) edge. They are located } \\
\text { in the Central (one region), } \\
\text { Volga (one region), Southern } \\
\text { (two regions), North Caucasus } \\
\text { (four regions), Siberian (three } \\
\text { regions), and Far Eastern (two } \\
\text { regions) federal districts. }\end{array}$ \\
\hline
\end{tabular}

Table 3. Regions with maximum and minimum values of indicators

Note: Achieved by the authors on the base of table 1

Table 3 provides information on the geographical location of regions with high (column 2) and low (column 3) values of the share of innovative organizations in 2019. The analysis of this information showed that there was no correlation between the values of the indicators for the regions and their territorial location. Thus, we can state the confirmation of the third hypothesis.

\section{Conclusion}

The purpose of the study, which was to assess the levels of innovation use based on the share of innovative organizations in the total number of organizations in the regions of Russia for 2017-2019, was achieved. The conclusions that have scientific novelty and originality include:

1. The methodology for estimating the share of innovative organizations in the total number of organizations in the regions of Russia is presented. 
2. Modeling of the distribution of indicators based on data for 2017 , 2018, and 2019 was carried out.

3. It is proved that the values of the share of innovative organizations in the total number of organizations have not changed significantly over the years considered.

4. It is shown that almost every fifth organization in Russia showed some innovative activity during the period under review.

5. It is shown that the values of the specific weights of innovative organizations were significantly differentiated by region.

6. The regions with the maximum and minimum values of the share of innovative organizations in their total number are identified.

7. It is proved that there is no influence of the territorial location of the regions on the minimum and maximum values of the considered indicators.

8. It is shown that even the regions with the largest share of innovative organizations (the cities of Moscow and St. Petersburg) have not yet reached the level defined in the Presidential Decree No. 204 (2018).

The results of our work have a certain theoretical and practical significance. The methodological approach presented in the article to estimate the share of innovative organizations in the total number of organizations in the regions of Russia can be used in further research. Namely, when monitoring the share of innovative organizations in the regions and municipalities of Russia. The results of the work can be applied in the current activities of state structures and public organizations, when justifying measures to support innovation activities in accordance with Presidential Decree No. 204 (2018).

In addition, the information obtained can be used to solve problems of increasing the share of innovative organizations in regions where such organizations are not widely developed. The results of the work are of interest to leasing companies that ensure the introduction of new equipment and advanced technologies. The new knowledge gained is of interest and can be used in the educational process at universities.

Further research can be conducted to assess the industry characteristics specific to innovative organizations. In the course of the study, there were no restrictions on empirical data, since information was considered for all 82 regions of Russia. 
Iuliia S. Pinkovetskaia, Natalya R. Aleksandrova, Tatyana V. Treskova y Daniela S. Veas Iniesta Present Innovation Policy: Russian Regions Data

\section{Bibliographic References}

ARKHIPOVA, Marina Yuryevna; SIROTIN, Vyacheslav Pavlovich; AFONINA, Vera Evgenyevna. 2019. "Modeling of innovative activity of small and medium-sized businesses" In: Intelligence. Innovation. Investment. No. 5, pp. 20-30. Available online. In: https://www.elibrary.ru/item. asp?id=41328804. Consultation date: $10 / 12 / 2020$.

BELEMAEVA, Anastasiya Vyacheslavovna; KALIMULLIN, Denis Maratovich. 2020. "Analysis of the significance of innovation assessment in the process of increasing the capitalization of an enterprise" In: Economics and Business: theory and practice. No. 1-1, No. 59, pp. 35-38. Available online. In: https://www.elibrary.ru/item.asp?id=42359600. Consultation date: 10/12/2020.

BENAIM, Mickael; TETHER, Bruce. 2016. "Innovation Policies for a Creative Economy. Challenging the Dominance of STI and Research", presented at the EU-SPRI Conference, Lund, Sweden, 8-10 June.

BERGEK, Anna; JACOBSSON, Staffan; CARLSSON, Bo; LINDMARK, Sven; RICKNE, Annika. 2008. "Analyzing the Functional Dynamics of Technological Innovation Systems: A Scheme of Analysis" In: Research Policy. Vol. 37, pp. 407-429. Available online. In: https://www.sciencedirect.com/science/article/abs/pii/Soo487 3330700248X?via\%3Dihub. Consultation date: 15/12/2020.

BORRAS, Susana; EDQUIST, Charles. 2013. "The choice of innovation policy instruments" In: Technological forecasting and social change. Vol. 8o(8), pp. 1513-1522. Available online. In: https://www.researchgate. net/publication/269630694. Consultation date: 15/12/2020.

CASTELLACCI, Fulcio; MEE LIE, Christine. 2015. "Do the Effects of R\&D Tax Credits Vary Across Industries? A Meta-regression Analysis" In: Research Policy. Vol. 44(4), pp. 819-32. Available online. In: https:// isiarticles.com/bundles/Article/pre/pdf/41704.pdf. Consultation date: 21/12/2020.

CHOI, Hee Youl. 2017. “Japan’s Science \& Technology Innovation Policy and Implementation System” In: Science and Technology Policy. Vol. 27 (3), pp. 44-49.

DEPUTATOVA, Elena Yurievna; PERELMAN, Mikhail Alexandrovich. 2020. "Aspects of studying consumer behavior in the context of innovations in retail" In: Economics and Business: theory and practice. No. 1-1, No. 59, pp. 101-104. Available online. In: https://www.elibrary.ru/item. asp?id $=44704407$. Consultation date: $12 / 12 / 2020$. 
EDLER, Jakob; FAGERBERG, Jan. 2017. "Innovation policy: what, why, and how" In: Oxford Review of Economic Policy. Vol. 3, No. 1, pp. 2-23. Available online. In: https://academic.oup.com/oxrep/article-abst ract/33/1/2/2972712?redirectedFrom=fulltext. Consultation date: $11 / 12 / 2020$.

EDQUIST, Charles. 2011. "Design of Innovation Policy through Diagnostic Analysis: Identification of Systemic Problems (or Failures)" In: Industrial and Corporate Change. Vol. 20, pp. 1-29. Available online. In: https://academic.oup.com/icc/article-abstract/20/6/1725/883257. Consultation date: 16/12/2020.

FAGERBERG, Jan. 2017. "Innovation policy: Rationales, lessons and challenges" In: Journal of Economic Surveys. April. pp. 1-20. Available online. In: https://www.researchgate.net/publication/303510349_ Innovation_policy_Rationales_lessons_and_challenges. Consultation date: $16 / 12 / 2020$.

FAGERBERG, Jan; LAESTADIUS, Staffan; MARTIN, Ben. 2016. “The Triple Challenge for Europe: The Economy, Climate Change, and Governance" In: Challenge. Vol. 59, No. 3, pp. 178-204. Available online. In: https:// ideas.repec.org/p/sru/ssewps/2016-18.html. Consultation date: $16 / 12 / 2020$.

FAGERBERG, Jan; SRHOLEC, Martin; VERSPAGEN, Bart. 2010. "The Role of Innovation in Development" In: Review of Economics and Institutions. Vol. 1, No. 2, pp. 1-29. Available online. In: https://core.ac.uk/download/ pdf/296446081.pdf. Consultation date: 16/12/2020.

FEDERAL STATE STATISTICS SERVICE. 2021. Science and innovation. Available online. In: https://rosstat.gov.ru/folder/14477?print=1. Consultation date: 15/01/2021.

FORAY, Dominique. 2018. "Smart specialization strategies as a case of mission oriented policy - a case study on the emergence of new policy practices" In: Industrial and Corporate Change. Vol. 27, No. 5, pp. 817-832. Available online. In: https://academic.oup.com/icc/article-abstract/27/5/817/50 91000?redirectedFrom=fulltext. Consultation date: 15/12/2020.

GEELS, Frank. 2004. "From sectoral systems of innovation to socio-technical systems: Insights about dynamics and change from sociology and institutional theory" In: Research policy. Vol. 33(6-7), pp. 897-920. Available online. In: https://www.sciencedirect.com/science/article/ abs/pii/Soo48733304000496. Consultation date: 15/12/2020. 
HAUSMAN, Ricardo; RODRIK, Dani. 2003. "Economic development as selfdiscovery" In: Journal of Development Economics. Vol. 72, No. 2, pp. 603-633. Available online. In: https://www.sciencedirect.com/science/ article/abs/pii/So30438780300124X. Consultation date: 22/12/2020.

HEKKERT, Marco; NEGRO, Simona. 2009. "Functions of Innovation Systems as a Framework to Understand Sustainable Technological Change: Empirical Evidence for Earlier Claims" In: Technological Forecasting and Social Change. Vol. 76, pp. 584-594. Available online. In: https:// www.sciencedirect.com/science/article/abs/pii/So040162508000905. Consultation date: 22/12/2020.

HOWLETT, Michael. 2011. Designing Public Policy: Principles and Instruments. Routledge. London, UK.

KARAKASHIAN, Sonia. 2015. "A software patent war: The effects of patent trolls on startup companies, innovation, and entrepreneurship" In: Hastings Bussiness Law Journal. No. 11, pp. 119-156. Available online. In: https://repository.uchastings.edu/hastings_business_law_journal/ vol11/iss1/6/. Consultation date: 22/12/2020.

KUDRYAVTSEVA, Svetlana. 2020. "Technological readiness of industry for open innovations" In: Economics in industry. Vol. 13, No. 1, pp. 48-58. Available online. In: https://ecoprom.misis.ru/jour/article/view/821. Consultation date: 22/12/2020.

KULHMANN, Stefan; RIP, Arie. 2014. "The Challenge of Addressing Grand Challenges", Brussels. Available online. In: https://research.utwente.nl/ en/publications/the-challenge-of-addressing-grand-challenges-a-thinkpiece-on-how. Consultation date: 10/12/2020.

LAREDO, Philippe; KOHLER, Christian; RAMMER, Christian. 2016. "The Impact of Fiscal Incentives for R\&D” In: J. Edler, P. Cunningham, A. Gok, and P. Shapira (eds), Handbook of Innovation Policy Impact, Cheltenham, Edward Elgar, pp. 18-53. Available online. In: https://www. elgaronline.com/view/edcoll/9781784711849/9781784711849.00009. xml. Consultation date: 10/12/2020.

LAUBER, Volkmar; JACOBSSON, Staffan. 2015. "Lessons from Germany's Energiewende" In: J. Fagerberg, S. Laestadius, and B. R. Martin (eds), The Triple Challenge for Europe: Economic Development, Climate Change and Governance, Oxford University Press, pp. 173-204.

LIPOVKA, Nina; ARNAUTOVA, Elena. 2020. "Influence of innovations on the enterprise economy" In: Actual problems and prospects of economic development: Russian and foreign experience. No. 1, No. 26, pp. 46- 
49. Available online. In: https://elibrary.ru/item.asp?id=42387035. Consultation date: 10/12/2020.

LIU, Xielin; WHITE, Steven. 2001. "Comparing innovation systems: a framework and application to China's transitional context” In: Research Policy. Vol. 30, pp. 1091-1114. Available online. In: https://www. sciencedirect.com/science/article/abs/pii/So048733300001323. Consultation date: 10/12/2020.

MARTIN, Ben. 2013. "Innovation Studies: An Emerging Agenda" In: J. Fagerberg, B. R. Martin, and E. Sloth Andersen (eds) In: Innovation Studies: Evolution and Future Challenges, Oxford, Oxford University Press, pp.168-186.

MARTIN, Ben. 2016. "R\&D Policy Instruments - A Critical Review of What We Do and Don't Know” Industry and Innovation. Vol. 23, pp. 157-176. Available online. In: https://www.tandfonline.com/doi/abs/10.1080/13 662716.2016.1146125. Consultation date: 10/12/2020.

MAZZUCATO, Mariana; PENNA, Caetano. 2016. "Beyond market failures: the market creating and shaping roles of state investment banks" In: Journal of Economic Policy Reform. Vol. 19(4), pp. 305-326. Available online. In: https://www.tandfonline.com/doi/abs/10.1080/17487870.2016.121 6416. Consultation date: 10/12/2020.

MAZZUCATO, Mariana; SEMIENIUK, Gregor. 2017. "Public Financing of Innovation: New Questions" In: Oxford Review of Economic Policy. Vol. 33(1), pp. 24-48. Available online. In: https://academic.oup.com/ oxrep/article/33/1/24/2972707. Consultation date: 10/12/2020.

MOHNEN, Pierre; VANKAN, Arthur; VERSPAGEN, Bart. 2017. "Evaluating the Innovation Box Tax Policy Instrument in the Netherlands, 2007-13" In: Oxford Review of Economic Policy. Vol. 33(1), pp. 141-156. Available online. In: https://academic.oup.com/oxrep/article-abstract/33/1/141/ 2972709? redirectedFrom=fulltext. Consultation date: 10/12/2020.

OECD. 2010. Measuring Innovation: A New Perspective, OECD Publishing. OECD iLibrary. Measuring Innovation: A New Perspective. Available online. In: oecd-ilibrary.org. Consultation date: 12/12/2020.

OECD/Eurostat. 2018. Oslo Manual 2018: Guidelines for Collecting, Reporting and Using Data on Innovation. The Measurement of Scientific, Technological and Innovation Activities, OECD Publishing, Paris/ Eurostat, Luxembourg. 258 p.

PETRIKOV, Anreu Vladimirovich. 2019. "Features of innovative development of the regions of the Central Federal District of the Russian Federation" 
In: The economy of sustainable development. No. 1, No. 37, pp. 64-66. Available online. In: https://www.elibrary.ru/item.asp?id=37274240. Consultation date: 18/12/2020.

PIERSON, Paul. 2000. "Increasing Returns, Path Dependence, and the Study of Politics" In: The American Political Science Review. Vol. 94, pp. 251267. Available online. In: https://www.jstor.org/stable/2586011?seq=1. Consultation date: 18/12/2020.

PINKOVETSKAIA, Iuliia; LEBEDEV, Anton; ROZHKOV, Mikhail; BEREZINA, Natalia. 2021. "Assessment of business infrastructure in 2018" In: Cuestiones Políticas. Vol. 39, No. 68, pp. 385-396. Available online. In: https://produccioncientificaluz.org/index.php/cuestiones/article/ view/35422/37523. Consultation date: 18/01/2021.

PINKOVETSKAIA, Iuliia; SLEPOVA, Vladislava. 2018. "Estimation of Fixed Capital Investment in SMEs: the Existing Differentiation in the Russian Federation” In: Business Systems Research. No. 9, No. 1, pp. 65-78. Available online. In: https://sciendo.com/article/10.2478/bsrj-2018o006. Consultation date: 17/12/2020.

PODSOLONKO, Vladimir; PODSOLONKO, Elena; SLEPOKUROV, Aleksandr. 2019. "Management of innovations and technology transfer for improving the efficiency of the economy" In: Scientific Bulletin: finance, banks, investments. No. 2, No. 47, pp. 136-151. Available online. In: https://www.elibrary.ru/item.asp?id=41324800. Consultation date: $17 / 12 / 2020$.

PRESIDENTIAL DECREE NO. 204. 2018. "On National Goals and Strategic Objectives for the Development of the Russian Federation for the period up to 2024". Available online. In: http://www.kremlin.ru/acts/ bank/43027. Consultation date: 17/12/2018.

RUBALCABA, Luis; MICHEL, Stefan; SUNDBO, Jon; BROWN, Stephen; REYNOSO, Javier. 2012. "Shaping, Organizing, and Rethinking Service Innovation: A Multidimensional Framework" In: Journal of Service Management. Vol. 23, No. 5, pp. 696-715. Available online. In: https:// www.emerald.com/insight/content/doi/10.1108/09564231211269847/ full/html. Consultation date: 17/12/2020.

SCHOT, Johan; STEINMUELLER, Edward. 2018. "New directions for innovation studies: missions and transformations" In: Research Policy. Vol. 47, pp. 1583-1584. Available online. In: https://www. researchgate.net/publication/327584341_New_directions_for_ innovation_studies_Missions_and_transformations. Consultation date: 17/12/2020. 
SMIRNOVA, Ann. 2020. "Innovations as the main tool for improving the competitiveness of Russian business structures" In: Science-practical research. No. 1-3, No. 24, pp. 237-243. Available online. In: https://www. elibrary.ru/item.asp?id=42359487. Consultation date: 17/12/2020.

SMITH, Keith. 2004. "Measuring Innovation” In: Fagerberg, J., Mowery, D., Nelson, R. (eds.), The Oxford Handbook of Innovation, Oxford, Oxford University Press, pp. 148-178.

SMITS, Ruud; KUHLMANN, Stefan. 2004. "The rise of systemic instruments in innovation policy" In: International Journal of Foresight and Innovation Policy. Vol. 1, pp. 4-32. Available online. In: https://www.researchgate. net/publication/200465408_The_rise_of_systemic_instruments_ in_innovation_policy_Int_J_Foresight_Innov_Policy_14-32. Consultation date: 10/12/2020.

TUNZELMANN, Nick; ACHA, Virginia. 2004. "Innovation in "Low-tech" Industries" In: J. Fagerberg, D. Mowery, and R. Nelson (eds), The Oxford Handbook of Innovation, Oxford, Oxford University Press, pp. 407-432.

VAN DER HAVE, Robert; RUBALCABA, Luis. 2016. "Social Innovation Research: An Emerging Area of Innovation Studies?” In: Research Policy. Vol. 45(9), pp. 1923-1935. Available online. In: https://www. sciencedirect.com/science/article/abs/pii/So04873331630107X. Consultation date: 10/12/2020.

WEBER, Matthias; TRUFFER, Bernhard. 2017. "Moving Innovation Systems Research to the Next Level: Towards an Integrative Agenda" In: Oxford Review of Economic Policy. Vol. 33, No. 1, pp. 101-121. Available online. In: https://academic.oup.com/oxrep/article-abstract/33/1/101/297271 3 ?redirectedFrom=fulltext. Consultation date: 10/12/2020.

YEZHOV, Albert Yurievich. 2020. "Modern problems of implementation and management of innovations in the Russian Federation" In: Innovations and investments. No. 2, pp. 12-14. Available online. In: http://innovazia.

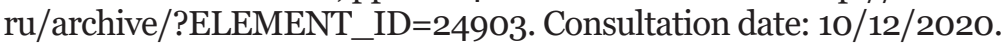

ZHURAVLEV, Denis Maksimovich. 2020. "Assessment of the technological readiness of the regional economy for the perception of innovations" In: Economic revival of Russia. No. 1, No. 63, pp. 138-147. Available online. In: https://www.elibrary.ru/item.asp?id=42543840. Consultation date: 21/12/2020. 
Vol. 39 N $^{\circ} 69$

Esta revista fue editada en formato digital y publicada en julio de 2021, por el Fondo Editorial Serbiluz, Universidad del Zulia. Maracaibo-Venezuela 